\title{
1. Constitutional foundations and EU institutional framework: seven years of working with Lisbon reform
}

\author{
Adam Łazowski and Steven Blockmans
}

\section{INTRODUCTION}

When the Treaty of Lisbon entered into force on 1 December 2009 hopes were high that the main points raised by the European Council in the Laeken Declaration had been sufficiently addressed and that the European Union was now better equipped to function smoothly and efficiently. ${ }^{1}$ The masterminds behind this treaty revision picked up the pieces of the failed constitutional reform and used some of the agreed measures as the point of departure for work on the negotiation mandate and then throughout the Intergovernmental Conference. These efforts aimed at, inter alia, simplification of the legal foundations of the Union as well as reform of the EU's institutional framework with the view of making it more democratic and more efficient. After two consecutive rounds of enlargement the number of Member States almost doubled, potentially exacerbating the already stretched EU's institutional framework. ${ }^{2}$ With 27 Member States on board, it was becoming increasingly difficult to remain 'united in diversity'. Although an EU of different speeds had been on the cards from the early days of European integration, it gained momentum with the entry into force of the Treaty of Maastricht, ${ }^{3}$ which cemented several opt-outs for the United Kingdom, Ireland and Denmark. The introduction of the enhanced co-operation mechanism by the Treaty of Amsterdam $^{4}$ was another step forward in this respect. The Union has undergone a painfully brokered institutional reform process since, and it is currently facing the biggest existential crisis in its history.

1 Treaty of Lisbon amending the Treaty on European Union and the Treaty establishing the European Community, signed at Lisbon, 13 December 2007, OJ 2007 C 306/1.

2 This, in a way, was acknowledged by drafters of the Treaty of Lisbon who formulated the preamble to the first draft of the Treaty rather bluntly. It provided that the new legal framework was there 'to complete the process started by the Treaty of Amsterdam and by the Treaty of Nice of adapting the institutions of the European Union to function in an enlarged Union'. Not surprisingly, this wording was later dropped and never made it to the Treaty of Lisbon. See Draft Treaty amending the Treaty on European Union and the Treaty establishing the European Community. Draft Preamble, Brussels 24 July 2007, CIG 4/07.

3 Treaty on European Union, OJ 1992 C 191/1. See further, inter alia, D. O'Keeffe and P. Twomey (eds), Legal Issues of the Treaty of Maastricht, John Wiley \& Sons 1994.

4 Treaty of Amsterdam amending the Treaty on European Union, the Treaties establishing the European Communities and certain related acts, OJ 1997 C 340/1. See further, inter alia, D. O'Keeffe and P. Twomey (eds), Legal Issues of the Amsterdam Treaty, Hart Publishing 1999. 


\section{Research handbook on EU institutional law}

In this chapter we examine a number of intertwined reforms that aimed at enhancing the effectiveness of the European Union. The starting point is an overview of constitutional foundations of the EU, including the reformed Founding Treaties and catalogues of secondary legislation at the disposal of the EU decision-making authorities. It is followed by a critical analysis of the ever-faster drive towards a European Union of different speeds, which, as is argued here, may be a potential threat to the 'ever closer Union' that the Founding Treaties provide for. Finally, the centre of gravity of our attention moves to the key institutional reforms which have been implemented since the Treaty of Lisbon entered into force. A cliché it may be, but - as always with law - it is the everyday reality that serves best as a litmus paper to test what new laws are worth. EU law, and in this case the Treaty of Lisbon, are no exception in this respect.

\section{CONSTITUTIONAL FOUNDATIONS}

\subsection{Introduction}

The EU legal order, just like national legal systems or public international law, comprises many different sources. In the case of the EU, the current state of affairs is a direct result of constant evolution through consecutive treaty changes and the dynamic practice of EU institutions. The Treaty of Lisbon brought about a number of crucial changes to the then existing system. The aim of this section is to track down that evolution with a view to answering the pivotal question of whether recent reforms have been a successful quest for simplification. Obviously, a firm and simplified answer 'yes' or 'no' is neither desired nor possible. In some ways, the reforms introduced by the Treaty of Lisbon have added to the clarity of EU sources of law. Alas, some of the novelties are a far cry from the objectives laid down in the Laeken Declaration. They are living proof that - as acutely observed by the European Convention - nothing is more complicated than simplification. ${ }^{5}$

Before going any further it is worth asking a fundamental question: why a simplification was desired when the Member States drafted the Laeken Declaration and, subsequently, when the European Convention made the first attempt at the European Constitution? A trivial, yet fully correct answer is because the then applicable system of sources was complicated and beyond comprehension for an average EU citizen. On the one hand, that diagnosis was correct. On the other hand, one could say - quite cynically - that the same applies to the national legal orders, which quite frequently remain a mystery for the citizens of the Member States. However, one of the main objectives behind the constitutional reform was to bring the EU closer to its citizens. It was relatively easy to set that objective, yet its implementation proved to be a rather difficult experience. The analysis that follows is organised in the following manner. First, the post-Lisbon Treaty framework is looked at in section 2.2. Then, in

5 European Convention, Final report of Working Group IX on Simplification, CONV 424/02, p. 1 . 
section 2.3, changes introduced by the Treaty of Lisbon to types of EU secondary legislation at the disposal of EU institutions are presented.

\subsection{Post-Lisbon Treaty Framework}

\subsubsection{An overview of the Treaty framework}

The failure of the Treaty establishing a Constitution for Europe put to an end to the ambitious aim of streamlining the structure of primary law by equipping the European Union with a single treaty. For obvious reasons, what became the Treaty of Lisbon had to take the shape of a revision treaty amending the then existing treaty framework. Any other option would have brought back the ghosts of the Constitution and, by this token, would have made reform politically more difficult. ${ }^{6}$ With the replacement of a batch of Treaties with a single new document no longer on agenda, a politically viable solution for a slightly more modest simplification was pursued. Abolition of the European Community and the three-pillar structure of the European Union were a catalyst in this respect. A full merger of the Treaty establishing European Community with the Treaty on European Union was not politically acceptable, hence the drafters opted for a safer option, that is, the rebranding of the first into the Treaty on Functioning of the European Union. This was not an entirely novel idea as such an option was put forward in the Laeken Declaration. ${ }^{7}$ At the same time the Member States decided to keep the European Atomic Energy Community as a separate entity with its own Treaty serving as a legal basis. Finally, the Charter of Fundamental Rights was no longer meant to be part of the Treaty framework but became binding and gained the status of primary law qua a cross-reference in the revised Article 6 TEU. All these issues are analysed in turn.

\subsubsection{The relationship between the Founding Treaties}

Looking at the post-Lisbon structure of the Founding Treaties, comprising three legal acts, one can come to the conclusion that the pursuit of simplification has failed. This is truly so. Clearly the politics has prevailed over sound law-making and, with the current lack of appetite for any future revision of the Founding Treaties, the contemporary treaty framework is the one that everyone has to get used to. At the same time, however, it is worth noting that the abolition of the EU three-pillar structure, although gradual, has contributed to some simplification.

At this stage of the analysis it is worth paying attention to two matters: the allocation of dossiers between the Treaty on European Union, the Treaty on Functioning of the European Union and the Euratom Treaty, as well as the relationship between the three Founding Treaties. All have undergone some pruning and stitching as part of the reform

6 In broader terms, the package of reforms agreed to in the Treaty establishing a Constitution for Europe had to be de-constitutionalised to avoid accusations that a Treaty that had been rejected by voters in France and the Netherlands was now reintroduced through the back door.

7 The European Convention considered streamlining the Treaty structure as a point of departure. One of the questions raised in the Laeken Declaration is whether the European Union should have a 'basic treaty and the other treaty provisions'. Interestingly enough, the concept of a constitutional text was presented as a long-term option. 
provided for by the Treaty of Lisbon. To begin with, unlike before, the Treaty on European Union now deals with the basics of the institutional structure of the European Union, while further details are regulated in the Treaty on Functioning of the European Union. The splitting of provisions into two legal acts makes them tricky to navigate. Although it is hard to imagine that an average EU citizen would express a desire to delve into the Founding Treaties for leisure, still, however, if the Lisbon Treaty were to bring the EU closer to its citizens it may have failed to do so on this account.

While the allocation of dossiers between the Treaties is generally sound, in some cases it - rightly so - raises questions. As mentioned in the introductory chapter to this volume, one of the critical issues identified in the Laeken Declaration was a division of competences between the European Union and the Member States. This was addressed in the Treaty establishing a Constitution for Europe ${ }^{8}$ and, it is accordingly dealt with in the Treaty of Lisbon. ${ }^{9}$ While this matter is thoroughly discussed by Claes and de Witte in Chapter 2 of this book, it is worth noting here that the location of catalogues of various EU competences is surprising, to say the least. Arguably, matters of such fundamental importance belong to those constitutional aspects of European integration that deserve to be regulated at the beginning of the Treaty on European Union. Alas, all relevant provisions found their home in the Treaty on Functioning of the European Union. Since both Treaties have the same legal value, and in formal terms this location of the provisions in question does not make much of a difference, symbolically it is not very convincing.

An area where the Lisbon Treaty has brought quite considerable changes, both to the institutional set-up and also in substantive terms, is external relations. ${ }^{10}$ Drafters of the Treaty of Lisbon opted for consolidation of numerous provisions which previously had been scattered around the Treaty establishing the European Community. This is a very welcome development; however, rules governing EU external relations are still divided between the Treaty on European Union, ${ }^{11}$ the Treaty on Functioning of the European Union $^{12}$ and the Euratom Treaty. ${ }^{13}$ The general principles on external action as well as the Common Foreign and Security Policy (CFSP) are separated from the rest as they are regulated in a tailor-made chapter of the Treaty on European Union. ${ }^{14}$ Thus, the CFSP is the only EU policy which is regulated in the Treaty on European Union, while others have their legal bases in the TFEU and the Euratom Treaty. On the one hand, it may look like an anomaly to separate different strands of EU external action while the spirit of the Lisbon Treaty is to join them up; on the other hand, the EU legislator - in all likelihood - opted for maintaining the status quo in order to emphasise the 'specific' character of CFSP, that is, different modi operandi and instruments from those

\footnotetext{
8 See Articles I-11-I-17 of the Treaty establishing a Constitution for Europe.

9 Articles 3-6 TFEU.

10 See further, inter alia, P.J. Cardwell (ed), EU External Relations Law and Policy in the Post-Lisbon Era, T.M.C. Asser Press 2012.

11 See Arts 21-46 TEU.

12 See Arts 205-221 TFEU.

13 Arts 101-106 Euratom Treaty.

14 The only exception is Article 8 TEU dealing with relations between the European Union and its neighbourhood.
} 
employed for the implementation of TFEU-based policies. In a way, the remains of the former second pillar are intact and well preserved for the future.

As a result of the reform based on the Treaty of Lisbon, an interesting question emerges as to the relationship between these three Founding Treaties. This is not a new issue to be dealt with as, prior to the Treaty of Lisbon, the European Union and the European Communities had existed on the basis of multiple treaties which delimited areas falling under respective frameworks. The bone of contention was the division of competences between the European Community and the European Union, so the first pillar, on the one hand, and the second and third pillars, on the other. The interpretation of the then Article 47 TEU led, as is well known, to litigation at the Court of Justice. ${ }^{15}$ However, these disputes were about the competences as well as the choice of different procedures, the actors involved and the legal instruments used. The problem was not a technical relationship between the Treaties per se. Now, that the three pillars of the Union are gone, the relationship between the three Founding Treaties is to a greater extent a technicality, though not exclusively.

It should be noted that Article 1 TEU clarifies that both the Treaty on European Union and the Treaty on Functioning of the European Union complement one another and have the same legal value. Although formally this is true, one cannot escape the feeling that with its basic provisions on the aims and values of the EU, its institutional structure and treaty revision procedures, as well as membership and exit clauses, the Treaty on European Union may be considered as a mini-Constitution. In substantive terms, Article $40 \mathrm{TEU}$ resembles the former Article $47 \mathrm{TEU}$ as it delimits the application of TFEU and TEU in the area of external relations. ${ }^{16}$

The relationship between, on the one hand, the Treaty on European Union and the Treaty on Functioning of the European Union, and, on the other hand, the Euratom Treaty is not explicitly addressed. It can be argued, however, that they all have the same legal value. It is notable that the Treaty of Lisbon provided for some pollarding of the latter with only a selection of substantive provisions kept in force. All institutional provisions of Euratom were repealed with relevant sections of the TEU and TFEU applicable also to decision-making procedures based on the Euratom Treaty. ${ }^{17}$ It would have served the simplification to abolish the Euratom altogether and, for instance, to maintain some of its provisions and institutional idiosyncrasies by adding relevant sections to the TEU and the TFEU. This, however, was not acceptable to some Member States.

15 See, for instance, Case C-176/03, Commission of the European Communities v Council of the European Union, ECLI:EU:C:2005:542.

16 See more in section 5 below and in Chapter 2 of this volume.

17 See Article 106a of the Euratom Treaty. 


\subsubsection{The Charter of Fundamental Rights of the European Union as a primary source of EU Law}

The origins of the Charter of Fundamental Rights are well known and documented in the academic literature. ${ }^{18}$ Ever since its first version was officially proclaimed ahead of the Nice Summit in 2000, the role of the EU's own bill of rights has been constantly growing. In the Nice-Lisbon period the Charter remained a non-binding catalogue of rights, constituting a mix of existing EU law rights and selected provisions of ECHR. Its non-binding character did not stop the Court of Justice, the Court of First Instance and national courts from making references to it, which, however, were largely thrown in en passant and followed references to the ECHR. The status of the Charter was supposed to change when the drafters of the Constitutional Treaty decided to equip it with binding force and to transform it into, what eventually became, part two of the Constitution. Following the latter's demise, the Charter was resuscitated during the negotiations of the Lisbon Treaty. Still, in order to de-constitutionalise the new Treaty, the Charter was left out of the main text. ${ }^{19}$ As already mentioned, a kitchen door option was chosen allowing binding force to be given to the Charter by means of a simple cross-reference in amended Article 6 TEU. This, arguably, does not affect its status per $s e .{ }^{20}$ Article 6 TEU makes it clear that the Charter of Fundamental Rights has the same status as the Treaties, therefore it can be classed as primary law.

Seven years after the entry into force of the Treaty of Lisbon one is allowed to conclude that the Charter of Fundamental Rights has become a powerful instrument that the Court of Justice does not shy away from using. It is unquestionable that the Court of Justice has gone a long way from a mere en passant reference in Case C-555/07 Seda Kücükdeveci ${ }^{21}$ to, what some may call, shooting from the hip in Cases C-399/11 Melloni ${ }^{22}$ and C-617/10 Fransson. ${ }^{23}$ Undoubtedly the Charter is now a persuasive source of rights that the EU judicial institutions are ready to invoke. ${ }^{24}$ In Opinion 2/13 the Court of Justice argued that '[...] at the heart of that legal structure

18 For more on the history of the Charter of Fundamental Rights see, inter alia, G. de Búrca, 'The Drafting of the European Union Charter of Fundamental Rights', 26 ELRev (2001) p. 126.

19 P. Craig, 'The Treaty of Lisbon, Process, Architecture and Substance', 33 ELRev (2008) p. 137 , at p. 165 .

20 This, as argued in the academic literature, has the same effect that it would have had, had the Charter been formally part of the Founding Treaties. See M. Borowski, 'The Charter of Fundamental Rights in the Treaty on European Union' in M. Trybus and L. Rubini (eds), The Treaty of Lisbon and the Future of European Law and Policy, Edward Elgar Publishing 2012, p. 200, at p. 208.

21 Case C-555/07, Seda Kücükdeveci v Swedex GmbH \& Co. KG, ECLI:EU:C:2010:21.

22 Case C-399/11, Stefano Melloni v Ministerio Fiscal, ECLI:EU:C:2013:107.

23 Case C-617/10, Akklagaren v Hans Åkerberg Fransson, EU:C:2013:105.

24 D. Sarmiento, 'Who's Afraid of the Charter? The Court of Justice, National Courts and the New Framework of Fundamental Rights Protection in Europe', 50 CMLRev (2013) p. 1267, at p. 1269. See, inter alia, S. Iglesias Sánchez, 'The Court and the Charter: The Impact of the Entry into Force of the Lisbon Treaty on the ECJ's Approach to Fundamental Rights', 49 CMLRev (2012) p. 1565. 
[of the EU] are the fundamental rights recognised by the Charter'. ${ }^{25}$ Now that the Court of Justice has delayed the EU's accession to the ECHR, the Charter will remain for the foreseeable future the main source of fundamental rights in the European Union. ${ }^{26}$ By the same token, one should expect proliferation of the jurisprudence of the Court of Justice dealing with the Charter. Some of those future cases are likely to touch upon the interpretation of rights, freedoms and principles laid down therein. One may also expect a fair amount of jurisprudence touching upon the scope of application of the EU's bill of rights. The latter is what the Court of Justice has been asked to deal with already. This, in fact, boils down to interpretation of Article 51 of the Charter, which determines the scope of its application. It provides that the Charter applies to the EU institutions and to the Member States but, in the case of the latter, only to the extent they implement EU law. The amount of non-admissible references for preliminary ruling, asking for interpretation of the Charter, demonstrates that interpretation of this not very fortunate phrase is far from easy. ${ }^{27}$ Not only is the notion of 'implementation' rather ambiguous, but also discrepancies between various language versions of the Charter and inconsistency between the Charter and official explanatory notes lead to unnecessary lack of clarity. To begin with, some language versions use the term 'implementation', some, however, employ the word 'application'.${ }^{28}$ The latter is a much broader term. This, when put against the explanatory note and a prior case-law of the Court of Justice, creates a confusion. This has been reflected in queries of national courts and kept the judges at Kirchberg busy over the past few years. It was clarified by the Court of Justice in the already mentioned case C-617/10 Fransson. The Court of Justice ruled as follows:

Since the fundamental rights guaranteed by the Charter must [...] be complied with where national legislation falls within the scope of European Union law, situations cannot exist which are covered in that way by European Union law without those fundamental rights

25 Opinion 2/13 of the Court of 18 December 2014: Accession by the Union to the European Convention for the Protection of Human Rights and Fundamental Freedoms, ECLI:EU:C:2014:2454, para 169.

26 Not surprisingly Opinion $2 / 13$ has attracted a lot of academic commentary. See, inter alia, D. Halberstam, "It's the Autonomy, Stupid!" A Modest Defense of Opinion 2/13 on EU Accession to the ECHR, and the Way Forward', 16 GLJ (2015) p. 105; C. Krenn, 'Autonomy and Effectiveness as Common Concerns: A Path to ECHR Accession After Opinion 2/13', 16 GLJ (2015) p. 147; S. Øby Johansen, 'The Reinterpretation of TFEU Article 344 in Opinion 2/13 and its Potential Consequences', 16 GLJ (2015) p. 169; A. Łazowski and R.A. Wessel, 'When Caveats Turn into Locks: Opinion 2/13 on Accession of the European Union to the ECHR', 16 GLJ (2015) p. 179; S. Peers, 'The EU's Accession to the ECHR: The Dream Becomes a Nightmare', 16 GLJ (2015) p. 213.

27 See, inter alia, Case C-339/10, Krasimir Asparuhov Estov and Others $v$ Ministerski savet na Republika Bulgaria, ECLI:EU:C:2010:680; Case C-282/14, Stylinart sp. z o.o. v Skarbowi Państwa - Wojewodzie Podkarpackiemu, Skarbowi Państwa - Prezydentowi Miasta Przemyśla, ECLI:EU:C:2014:2486.

28 For instance, according to the Polish version of the Charter it applies when Member States apply ['stosują'] EU law. 
being applicable. The applicability of European Union law entails applicability of the fundamental rights guaranteed by the Charter. ${ }^{29}$

Interestingly enough, the Court of Justice returned to the literal reading of Article 51 of the Charter in its subsequent case-law, including Opinion $2 / 13^{30}$ as well as a very controversial case C-333/13 Dano. ${ }^{31}$

As noted in the previous paragraph, the Charter of Fundamental Rights has become a very frequent visitor at the Court of Justice of the European Union. It merits attention that a great majority of judgments dealing with the Charter are preliminary rulings submitted to the Court of Justice by domestic courts. This reflects the growing interest of litigants in the rights stemming from the Charter as well as potential problems with its interpretation. Apart from the already mentioned confusion as to the Charter's scope of application to the Member States, the possibility of producing direct effect, particularly in horizontal situations, has been one of the question marks. ${ }^{32}$ The Charter has also been invoked in actions for annulment; ${ }^{33}$ furthermore it has served as a

29 Para 21. See further on this judgment and, more broadly, on the application of the Charter to the Member States, inter alia, M. Dougan, 'Judicial Review of Member State Action under the General Principles and the Charter: Defining the "Scope of Union Law", 52 CMLRev (2015) p. 1201; E. Hancox, 'The Meaning of "Implementing" EU Law under Article 51(1) of the Charter: Åkerberg Fransson', 50 CMLRev (2013) p. 1411; M. Szwarc, 'Application of the Charter of Fundamental Rights in the Context of Sanctions Imposed by Member States for Infringements of EU Law: Comment on Fransson Case', 20 EPL (2014) p. 229; J. Vervaele, 'The Application of the EU Charter of Fundamental Rights (CFR) and its Ne bis in idem Principle in the Member States of the EU', 1 REALaw (2013) p. 113; B. Van Bockel and P. Wattel, 'New Wine into Old Wineskins: The Scope of the Charter of Fundamental Rights of the EU after Åkerberg Fransson', 38 ELRev (2013) p. 866.

30 Para 171 of the Opinion.

31 Case C-333/13, Elisabeta Dano and Florin Dano $v$ Jobcenter Leipzig, ECLI: EU:C:2014:2358, para 87. For criticism see N. Nic Shuibhne, 'The Right to Move and Reside: Disentangling the Dual Dynamics of Fundamental Rights in EU Citizenship Law', in S. Douglas-Scott and N. Hatzis (eds), Research Handbook on EU Human Rights Law, Edward Elgar Publishing 2017 (forthcoming). See further, inter alia, D. Thym, 'When Union Citizens Turn into Illegal Migrants: The Dano Case', 40 ELRev (2015) p. 249; H. Verschueren, 'Preventing "Benefit Tourism" in the EU: A Narrow or Broad Interpretation of the Possibilities Offered by the ECJ in Dano?', 52 CMLRev (2015) p. 363; S. Peers, 'Benefits for EU Citizens: A U-turn by the Court of Justice?', 74 CLJ (2015) p. 195.

32 Case C-176/12, Association de médiation sociale v Union locale des syndicats CGT and Others, ECLI:EU:C:2014:2. See further, inter alia, D. Leczykiewicz, 'Horizontal Application of the Charter of Fundamental Rights', 38 ELRev (2013) p. 479; N. Lazzerini, '(Some of) the Fundamental Rights Granted by the Charter may be a Source of Obligations for Private Parties: AMS', 51 CMLRev (2014) p. 907; E. Frantziou, 'Case C-176/12 Association de mediation sociale: Some Reflections on the Horizontal Effect of the Charter and the Reach of Fundamental Employment Rights in the European Union', 9 EUConst (2014) p. 332; E. Frantziou, 'The Horizontal Effect of the Charter of Fundamental Rights of the EU: Rediscovering the Reasons for Horizontality', 21 ELJ (2015) p. 657.

33 Case C-583/11P, Inuit Tapiriit Kanatami and Others $v$ European Parliament and Council of the European Union, ECLI:EU:C:2013:625. 
yardstick for review of legality under Article 267 TFEU $^{34}$ and a basis for the EU's liability in damages to private parties. ${ }^{35}$ However, the European Commission so far has been quite reluctant to invoke the Charter in infraction proceedings based on Articles 258 and 260 TFEU. As argued by one of the present authors elsewhere, this trepidation is not accidental but rather a well-considered policy choice taking into account a lack of clarity stemming from Article 51 regulating the scope of application of the Charter. ${ }^{36}$

When the Charter of Fundamental Rights became binding in 2009 in many ways it was a legal enigma. Since then it has been partly decoded by the Court of Justice, however further jurisprudential effort is necessary. By delaying the accession of the European Union to the ECHR, the Court of Justice has given itself ample opportunities to develop further its jurisprudence on the Charter and also general principles of EU law.

\subsection{Secondary Legislation}

\subsubsection{Introduction}

Simplification of secondary legislation as well as delimitation between legislative and implementing legislation was one of the tasks of the European Convention. In its Laeken Declaration, the European Council made it clear that the then existing system needed a reform as the proliferation of types of legal instruments through subsequent treaty revisions as well as inflation of very detailed legislation made the system difficult to navigate. ${ }^{37}$ It also triggered a very justified question whether the overall number of legal acts should be reduced to avoid overregulation. Hence, the Laeken Declaration suggested downsizing the catalogue of types of secondary legislation available to the EU decision-making authorities and having a debate about the levels of detail that future secondary legislation should have. Drafters of the Treaty establishing a Constitution for Europe opted for a radical solution and a complete rebranding of types of EU secondary legislation and the introduction of new typologies. ${ }^{38}$ This was a theoretically sound proposition, yet not much attention was paid to the procedural consequences of such a big change. One can only imagine armies of lawyers engaged in rebranding all existing EU acquis to meet the new constitutional standard or, in a worst case scenario, the co-existence of pre-Constitution secondary legislation and the slow phasing in of the new typology. The solutions agreed to in the European

34 See, inter alia, Case C-236/09, Association Belge des Consommateurs Test-Achats ASBL and Others v Conseil des ministres, ECLI:EU:C:2011:100, Case C-291/12, Michael Schwarz v Stadt Bochum, ECLI:EU:C:2013:670.

35 Case C-40/12P, Gascogne Sack Deutschland GmbH v European Commission, ECLI:EU:C:2013:768.

36 A. Łazowski, 'Decoding a Legal Enigma: The Charter of Fundamental Rights of the European Union and Infringement Proceedings', 14(4) ERA Forum (2013) p. 573.

37 As noted in the Final report of Working Group IX on Simplification, the European Union and the European Communities had 15 different legal instruments at their disposal (see Final report, loc. cit. n. 5, at p. 3).

38 See Arts I-33-I-39 of Treaty establishing a Constitution for Europe. For a commentary see, inter alia, T. Ćapeta, 'Legal Instruments in the Reform Treaty - Simplified?', 3 CYELP (2007) p. 157, at pp. 159-168; M. Dougan, 'The Convention's Draft Constitutional Treaty: Bringing Europe Closer to its Lawyers?', 28 ELRev (2003) p. 763, at pp. 781-787. 
Constitution were only partly taken on board during preparation of the Treaty of Lisbon. To begin with, the idea of introducing laws, framework laws instead of regulations and directives was abandoned. At the same time, the separate catalogue of secondary legislation for the third pillar was abolished with a set of transitional rules to apply as of entry into force of the Treaty of Lisbon. As part of the simplification exercise, the catalogue of secondary legislation applicable to the second pillar was streamlined, yet specificities have been maintained. Last but not least, the Treaty of Lisbon introduced badly needed division into legislative and non-legislative acts. Alas, this has not been controversy free as the latter category is divided into implementing and delegated acts, which sometimes are difficult to distinguish. Furthermore, some pieces of secondary legislation adopted on the basis of TFEU are neither legislative nor non-legislative acts. ${ }^{39}$ All these issues are analysed in turn.

\subsubsection{New typology of secondary legislation}

As already noted, the Treaty of Lisbon did not change the basic two types of secondary legislation. As per Article 288 TFEU the European Union adopts regulations and directives. The first are directly applicable, the second always require transposition into national laws. It should be noted, however, that many regulations - although directly applicable - require domestic measures facilitating their application in everyday practice.

However, the Treaty of Lisbon has introduced a new typology to EU secondary legislation..$^{40}$ Articles 289-291 TFEU provide for the division of these two types of secondary legislation into two main groups. All acts adopted as per ordinary or special legislative procedure constitute legislative acts. They may provide for the adoption of non-legislative acts, which take the form of delegated or implementing acts. In accordance with Article 290 TFEU, delegated acts are 'non-legislative acts of general application to supplement or amend certain non-essential elements of the legislative act'. Implementing acts, as Article 291 TFEU provides, are adopted 'where uniform conditions for implementing legally binding Union acts are needed' ${ }^{41}$ Both provisions entrust the European Commission with adoption of these types of legal acts. ${ }^{42}$

39 It should be noted that for the purposes of judicial review a notion of regulatory acts was introduced in Article 263 TFEU. Alas, it is not defined anywhere in the Founding Treaties, thus, not surprisingly, the Court of Justice has come to the rescue. See further Chapter 10 in this volume.

40 See further D. Curtin and T. Manucharyan, 'Legal Acts and Hierarchy of Norms in EU Law', in A. Arnull and D. Chalmers (eds), The Oxford Handbook of European Union Law, Oxford University Press 2015, p. 103; H. Hofmann, 'Legislation, Delegation and Implementation under the Treaty of Lisbon: Typology Meets Reality', 15 ELJ (2009) p. 482.

41 See further, inter alia, J. Bast, 'New Categories of Acts after the Lisbon Reform: Dynamics of Parliamentarization in EU Law', 49 CMLRev (2012) p. 885; P. Craig, 'Delegated Acts, Implementing Acts and the Comitology Regulation', 36 ELRev (2011) p. 671; S. Peers and M. Costa, 'Accountability for Delegated and Implementing Acts after the Treaty of Lisbon', 18 ELJ (2012) p. 427.

42 This section draws in part on S. Piedrafita and S. Blockmans, 'Shifting EU Institutional Reform into High Gear', Report of the High-level Group Chaired by Danuta Hübner, CEPS, March 2014. 
As far as delegated acts are concerned, Article 290 TFEU lays down basic substantive and procedural parameters. ${ }^{43}$ To begin with, details of the delegation of powers, including the content, scope and duration must be defined explicitly in legislative acts. At the same time an important caveat is provided for; the essential elements of a given area must be reserved for legislative acts. Au contraire, such essential elements cannot be the subject of a delegation. ${ }^{44}$ Two important procedural rules stem from Article 290(2) TFEU. First, the European Parliament and the Council may revoke the delegation. Second, delegated acts may only enter into force if no objections are raised by these two institutions within a deadline set in a legislative act on which delegated legislation is based. ${ }^{45}$ Since the entry into force of the Treaty of Lisbon, the European Commission has adopted under Article 290 TFEU over 240 delegated acts. ${ }^{46}$ Only the European Parliament has raised a few objections, which were eventually withdrawn after an exchange of views with the European Commission.

The application of Article 291 TFEU, and the adoption of the implementing acts it provides for, required a revision of the existing comitology system. For this purpose Regulation 182/2011/EU was adopted in 2011.47 In the case of implementing acts, the Commission's proposals must be examined by committees of national representatives, which takes place in the course of two alternatively used procedures. In the advisory procedure, the committee's opinion is not binding for the European Commission, whereas in the examination procedure, the Commission cannot adopt an implementing act in the event of a negative opinion. However, it can refer the case to the appeal committee, consisting of national representatives at a higher level of representation. In the event of a non-opinion in the appeal committee, the Commission tends to adopt the act in any case. So far this has happened in relation to an annual average of three to four implementing acts. ${ }^{48}$ Where a basic act is adopted under the ordinary legislative procedure, either the European Parliament or the Council may at any time indicate to the European Commission that, in its view, a draft implementing act exceeds the implementing powers provided for in the basic act. In such a case, the Commission

43 See further, B. Driesen, 'Delegated Legislation after the Treaty of Lisbon: An Analysis of Article 290 TFEU', 35 ELRev (2010) p. 847.

44 What stands behind the term 'essential' is still a source of controversy and litigation. See, inter alia, M. Chamon, 'How the Concept of Essential Elements of a Legislative Act Continues to Elude the Court: Parliament v. Council', 50 CMLRev (2013) p. 849.

45 In the preparation of the delegated acts, the Commission is held to consult experts from national authorities of all Member States and to send all the related information to the Council and the European Parliament. At the request of the EP, the Commission might also invite the Parliament's experts to attend the meetings. The EP and the Council have the right to object to a delegated act adopted by the Commission by the deadline specified in the original legislative act (usually two months, with a possible extension of two more).

46 Register of Commission documents (http://ec.europa.eu/transparency/regdoc/index.cfm? fuseaction=search).

47 Regulation (EU) No 182/2011 of the European Parliament and of the Council of 16 February 2011 laying down the rules and general principles concerning mechanisms for control by Member States of the Commission's exercise of implementing powers, OJ $2011 \mathrm{~L} \mathrm{55/13.}$

48 Comitology register: http://ec.europa.eu/transparency/regcomitology/index.cfm?do=List. list\&NewSearch=1. 
shall review the draft implementing act and inform the European Parliament and the Council whether it intends to maintain, amend or withdraw it. Since the entry into force of Regulation 182/2011/EU, the Commission has adopted several thousands of implementing acts -1700 of them in 2013 alone. ${ }^{49}$ Thus, the new system has not suffered in terms of efficiency, given that in the past a similar number of comitology decisions was taken per year.

The main weakness in the system introduced by the Lisbon Treaty is the thin line dividing delegated and implementing acts. ${ }^{50}$ On many occasions, either could be applied and EU institutions often disagree on which one to select. This choice thus becomes the object of negotiation during the adoption phase of a legislative act. The delegated acts give a greater leeway to the Commission and stronger oversight powers to the European Parliament, whereas the Member States have an important role to play in the adoption of implementing acts. It is therefore usual that the Council questions the (many) delegated acts in the Commission's proposals and pushes to change them into implementing acts during the negotiations with the European Parliament, which might be tempted to give way in exchange for concessions on the substance of the legislative act. ${ }^{51}$ This very issue has already led to litigation at the Court of Justice. ${ }^{52}$

\subsubsection{Phasing out of the second and third pillar acquis}

Following the entry into force of the Treaty of Maastricht the European Union has operated in the three pillar structure with different modi operandi and types of secondary legislation applicable to the Common Foreign and Security Policy and the Area of Freedom, Security and Justice. Reforms introduced by the Treaty of Amsterdam aimed at streamlining the system, yet they fell short of unification with the regime applicable to the then European Community. By the time of the European Convention, and the Intergovernmental Conference that followed it, the European Union had three separate catalogues of secondary legislation. ${ }^{53}$ As rightly noted in the Laeken Declaration, this constant proliferation of different instruments deserved to be addressed. It eventually happened during the negotiations of the Treaty of Lisbon, which - as already mentioned - considerably reduced the number of available types of secondary legislation.

To begin with, Article 9 of Protocol No 36 to the Founding Treaties provides that legal acts adopted prior to the entry into force of the Treaty of Lisbon in the third pillar of the European Union shall remain in force as long as they are not amended, repealed or replaced by new pieces of secondary legislation. This provision, rightly so, has triggered some controversy due to lack of precision. While the terms 'repeal' and

49 See the Committees' role in the European Commission's implementing powers, at http://eur-lex.europa.eu/legal-content/EN/TXT/?uri=URISERV:ai0043

50 See, inter alia, M. Chamon, 'Clarifying the Divide between Delegated and Implementing Acts?', 42 LIEI (2015) p. 175; D. Ritleng, 'The Dividing Line between Delegated and Implementing Acts: The Court of Justice Sidesteps the Difficulty in Commission v. Parliament and Council (Biocides)', 52 CMLRev (2015) p. 243.

51 S. Piedrafita and S. Blockmans, loc. cit. n. 42, at p. 24.

52 See, for instance, Case C-427/12, European Commission $v$ European Parliament and Council of the European Union, ECLI:EU:C:2014:170.

53 Article 249 EC Treaty, Article 12 TEU and Article 34 TEU. 
'replace' are rather self-explanatory, the notion of 'amendment' is vague to say the least. In purely theoretical terms one can justifiably question what constitutes it. For instance, does a mere revision of a preambular provision count as amendment? Seven years after the entry into force of the Treaty of Lisbon it seems clear that the European Commission has avoided controversy by not putting on the table amendments to the existing legislation, and by proposing replacement of older legal acts only in cases where negotiations of new measures would not lead to a backlash among the Member States and, by the same token, would not constitute a step back in the development of the Area of Freedom, Security and Justice. For instance, framework decisions on rights of victims in criminal proceedings ${ }^{54}$ or combating trafficking in human beings ${ }^{55}$ have been replaced with directives. ${ }^{56}$ At the same time, however, the European Commission has refrained from replacing Framework Decision 584/2002/JHA on the European Arrest Warrant ${ }^{57}$ and some other mutual recognition instruments with directives. It should be added that while framework decisions, as well as other third-pillar instruments, remain in force, the European Commission and the Court of Justice have received the jurisdiction, with the expiry of the transitional period on 1 December 2014, to scrutinise the compliance of the Member States with EU criminal law.

\subsection{Conclusions}

As argued in the preceding analysis, the quest for simplification of sources of EU primary and secondary law has been partly successful. The reform of primary law has provided some streamlining, yet the European Union is still based on two treaties, while a separate treaty regulates, albeit partly, the functioning of the European Atomic Energy Community. Clearly, there was a potential for far deeper streamlining at the time of the negotiations of the Treaty of Lisbon, yet the political climate was not favourable. At the same time, the European Union has finally received a binding catalogue of fundamental rights. This, arguably, was a long overdue development. The first seven years of the Charter serving as a binding catalogue of fundamental rights prove that the Court of Justice is still at the stage of unlocking the legal enigma. As argued in this chapter, by delaying the accession of the European Union to the ECHR,

54 Framework Decision 2001/220/JHA of 15 March 2001 on the standing of victims in criminal proceedings, OJ $2001 \mathrm{~L} 82 / 1$.

55 Council Framework Decision 2002/629/JHA of 19 July 2002 on combating trafficking in human beings, OJ 2002 L 203/1.

56 Directive 2012/29/EU of the European Parliament and of the Council of 25 October 2012 establishing minimum standards on the rights, support and protection of victims of crime, and replacing Council Framework Decision 2001/220/JHA, OJ 2010 L 315/57; Directive 2011/ 36/EU of the European Parliament and of the Council of 5 April 2011 on preventing and combating trafficking in human beings and protecting its victims, and replacing Council Framework Decision 2002/629/JHA, OJ 2011 L 101/1.

57 Council Framework Decision 2002/584/JHA of 13 June 2002 on the European arrest warrant and the surrender procedures between Member States, OJ 2002 L 190/1. For an academic appraisal see, inter alia, N. Keizer and E. van Sliedregt (eds), The European Arrest Warrant in Practice, T.M.C. Asser Press 2009. 
the judges at Kirchberg have given the Charter a chance to flourish in the years to come. Another important dual reform effort introduced by the Treaty of Lisbon was, on the one hand, abolition of different catalogues of sources of secondary legislation for the three pillars of the European Union and, on the other hand, introduction of a new typology of secondary legislation. As far as the first is concerned, it has clearly brought some efficiencies and led to the adoption of several directives governing EU criminal law. This is likely to lead to increased effectiveness of EU law, yet the indications so far are less than promising. To put it differently, the Member States continue to experience delays in the transposition of EU criminal law to the national legal orders. Introduction of a new typology of secondary legislation, that is a clearer division between legislative and non-legislative acts, has been marred with difficulties from the start. As noted earlier, it has proven to be rather difficult to draw a dividing line between delegated and implementing acts. So far this has led to several disputes and litigation at the Court of Justice. One is expecting a further clarification from the Court as to the differences between these two types of non-legislative acts. No doubt, this is a matter of high importance, both in political and legal terms.

\section{DIFFERENTIATION}

While the EU and its predecessors have been 'united in diversity' for the past decades, this unity has eventually started to erode. This, one may argue, is a price that had to be paid for the seven rounds of enlargement that have brought the number of Member States from the original six to 28. It is also a consequence of the growing competences of the European Union, which for some Member States, are hard to swallow. A third rationale can be found in the efforts to accommodate the divisions between Member States in tackling the interlocking crises confronting the Union. ${ }^{58}$

Accommodating 'differentiation' in EU law is no new phenomenon but a concept which has been integral to the European integration process since the Treaty of Rome. ${ }^{59}$ The concept is to be generally understood as a 'model of integration strategies that try to reconcile heterogeneity within the European Union and allow different groupings of Member States to pursue an array of public policies with different procedural and institutional arrangements'.$^{60}$ While considered a convenience to accommodate different socio-economic and political interests of Member States in an enlarging European Union, various models of flexible integration are increasingly provoking questions on where the constitutional, institutional and instrumental boundaries of 'variable geometry' lie in an organisation which is based on a special legal order with common institutions and common principles. ${ }^{61}$ Before analysing this further it is worth noting

\footnotetext{
58 Cf. the introductory chapter of this volume.

59 This section relies on S. Blockmans (ed), Differentiated Integration in the EU: From the Inside Looking Out, Brussels, CEPS 2014, at pp. 1-2.

60 A. Stubb, 'A Categorization of Differentiated Integration', 34 JCMS (1996) p. 283.

61 See in this respect already D. Curtin, 'The Constitutional Structure of the Union: A Europe of Bits and Pieces', 30 CMLRev (1993) p. 17; and N. Walker, 'Sovereignty and Differentiated Integration in the European Union', 4 ELJ (1998) p. 355. More recently, J-C.
} 
that a distinction between differentiation pro foro interno and pro foro externo can be made. Both are discussed in turn.

As noted earlier, the Founding Treaties are tools for the 'ever closer Union'. Yet they also provide several mechanisms for differentiation pro foro interno. To begin with, they envisage opt-outs from selected policies available to a few Member States. This includes opt-outs from the Area of Freedom, Security and Justice ${ }^{62}$ as well as the single currency. ${ }^{63}$ Furthermore, in the case of countries joining the European Union, phasing into Schengen acquis and Economic and Monetary Union is gradual. The modi operandi in this respect are provided in accession treaties. ${ }^{64}$ It should be also noted that some non-EU countries participate in Schengen co-operation, which adds new flavours to the concept of differentiated integration. ${ }^{65}$ In anticipation of potential problems with reaching consensus on new legislation, the Treaty of Amsterdam created an enhanced co-operation mechanism allowing smaller groups of Member States to integrate further in some areas when overall agreement of all countries is not feasible. The enhanced co-operation remained a 'lettre morte' of the Treaties for number of years; 66 however, since the entry into force of the Treaty of Lisbon, it has been used several times to adopt measures covering mutual recognition of judgments in divorce matters ${ }^{67}$ and for

Piris, The Future of Europe: Towards a Two-Speed EU?, Cambridge University Press 2011; P. Craig, 'Two-Speed, Multi-Speed and Europe's Future: A Review of Jean-Claude Piris on the Future of Europe', 37 ELRev (2012) p. 800.

62 The United Kingdom, Ireland and Denmark benefit from opt-outs in the Area of Freedom, Security and Justice, with the possibility of opting in on a case-by-case basis.

63 Since 1 January 2015, the Euro area comprises 19 Member States. With the exception of the UK and Denmark, which have opt-outs, the other Member States (the so-called 'pre-ins') are legally bound to join once they meet all the criteria. Sweden is not joining the ERM II in order to avoid compliance with one of the conditions (exchange rate stability) and thus the introduction of the euro. Monaco, San Marino and the Vatican use the euro on the basis of formal agreements with the EU, whereas Andorra, Kosovo and Montenegro use it de facto.

64 See for instance Treaty between the Kingdom of Belgium, the Republic of Bulgaria, the Czech Republic, the Kingdom of Denmark, the Federal Republic of Germany, the Republic of Estonia, Ireland, the Hellenic Republic, the Kingdom of Spain, the French Republic, the Italian Republic, the Republic of Cyprus, the Republic of Latvia, the Republic of Lithuania, the Grand Duchy of Luxembourg, the Republic of Hungary, the Republic of Malta, the Kingdom of the Netherlands, the Republic of Austria, the Republic of Poland, the Portuguese Republic, Romania, the Republic of Slovenia, the Slovak Republic, the Republic of Finland, the Kingdom of Sweden, the United Kingdom of Great Britain and Northern Ireland (Member States of the European Union) and the Republic of Croatia concerning the accession of the Republic of Croatia to the European Union, OJ 2012 L112/10.

65 Twenty-two EU Member States and the four EFTA countries participate in the Schengen Area. Monaco, San Marino and the Vatican can be considered as de facto members. Bulgaria, Croatia, Cyprus and Romania will eventually join when they meet the criteria, whereas Ireland and the UK have opt-outs.

66 With exception of the Schengen acquis which was incorporated into the EU legal order qua the Treaty of Amsterdam.

67 Council Regulation (EU) No 1259/2010 of 20 December implementing enhanced cooperation in the area of the law applicable to divorce and legal separation, OJ 2010 L 343/10. Sixteen Member States have decided to participate in this endeavour. This includes Austria, 
creation of a unitary EU patent. ${ }^{68}$ The latest episode in shaping a Europe of different speeds is the Treaty on Stability, Coordination and Governance (TSCG), better known as the Fiscal Compact. ${ }^{69}$ Circumventing a spectacular act of defiance exercised by the UK's government (later joined by the Czech Republic), the other Member States decided to step outside the EU legal framework in order to agree on a set of rules to deepen the integration in the wake of the sovereign debt crisis. ${ }^{70}$ At the same time, however, the Treaty provides that a possible incorporation of its rules into the EU legal order should be considered five years after its entry into force. Such a way of proceeding is not unheard of since the absorption of the Schengen acquis and the Prüm Convention.

The sovereign debt crisis and the handling of Greece to prevent it from crashing out of the Eurozone (nicknamed 'Grexit') have led to a thorough re-assessment of European integration as a whole, and Eurozone governance in particular. For the political leaders of some Member States the successive creation of a fiscal, economic and political union based on federal principles is the way forward. ${ }^{71}$ For others, the time has come to reassess their position in the European Union, either by securing

Belgium, Bulgaria, France, Germany, Hungary, Italy, Latvia, Luxembourg, Malta, Portugal, Romania, Slovenia and Spain (2011), Lithuania (2012) and Greece (2014).

68 Regulation (EU) No 1257/2012 of the European Parliament and of the Council of 17 December 2012 implementing enhanced cooperation in the area of the creation of unitary patent protection, OJ 2010 L 361/1. Twenty-five Member States signed up to the EU legislation on the patent with unitary effect. After Spain lost its challenges to the unitary patent package before the CJEU in Cases C-146/13, Kingdom of Spain v European Parliament and Council of the European Union, ECLI:EU:C:2015:298 and C-147/13, Kingdom of Spain v Council of the European Union, ECLI:EU:C:2015:299, Italy (which stood shoulder to shoulder with Spain in an earlier unsuccessful challenge to the Council before the Court in Case C-274/11, Kingdom of Spain and Italian Republic $v$ Council of the European Union, ECLI:EU:C:2013:240) dropped its opposition to the patent. This isolates Spain and Croatia and may lead to full integration of the EU patent before too long.

69 Treaty on Stability, Coordination and Governance in the Economic and Monetary Union between the Kingdom of Belgium, the Republic of Bulgaria, the Kingdom of Denmark, the Federal Republic of Germany, the Republic of Estonia, Ireland, the Hellenic Republic, the Kingdom of Spain, the French Republic, the Italian Republic, the Republic of Cyprus, the Republic of Latvia, the Republic of Lithuania, the Grand Duchy of Luxembourg, Hungary, Malta, the Kingdom of the Netherlands, the Republic of Austria, the Republic of Poland, the Portuguese Republic, Romania, the Republic of Slovenia, the Slovak Republic, the Republic of Finland and the Kingdom of Sweden. The TSCG was signed in 2013 by all EU Member States except the UK and the Czech Republic. Prague later reversed its position. Croatia was not a member of the EU at the time. Denmark and Romania are bound by the fiscal provisions, while these provisions will only apply to the remaining non-Eurozone states when they adopt the euro. All the Eurozone members take part in the European Stability Mechanism (ESM), and together with Bulgaria, Denmark, Lithuania, Poland and Romania all participate in the Euro-Plus Pact. The EP does not participate in the adoption of these agreements, as they are not part of the acquis and thus not subject to the CJEU's jurisdiction either. For a commentary see, inter alia, P. Craig, 'The Stability, Coordination and Governance Treaty: Principles, Politics and Pragmatism', 37 ELRev (2012) p. 231.

70 See further Chapter 3 in this volume.

71 See already the Final Report of the Future of Europe Group of the Foreign Ministers of Austria, Belgium, Denmark, France, Italy, Germany, Luxembourg, the Netherlands, Poland, 
further exceptions to the ground rules which define the level of European integration or by contemplating opting back into common policies. A good example of the first is the position taken by the United Kingdom on the preambular phrase 'ever closer union' ahead of the UK (in/out) referendum on EU Membership. As far as the latter is concerned, Denmark recently contemplated becoming more involved in the Area of Freedom, Security and Justice. ${ }^{72}$ In relation to Eurozone matters, there is a real risk of a 'two-tier' EU growing even further, that is, the development of a different institutional setting to decide on issues that only affect the Euro members. Apart from the existing Eurogroup and Euro Summits, ideas have been floated to create a special committee in the European Parliament or a Euro-chamber with members of national parliaments. Non-Eurozone members, especially the 'pre-ins' but also 'outs' such as the UK, are concerned about these developments. ${ }^{73}$ The gap between members and non-members of the Eurozone has nominally grown since phase 2 of the Lisbon voting provisions entered into force in November 2014, given that Euro members now constitute a qualified majority in the Council. ${ }^{74}$

Whereas stories of 'Grexit' and 'Brexit' have reignited the debate about the fragmentation of the EU system, another way of looking at the efforts to accommodate individual Member States' overriding national interests within the confines of the Treaties is to consider that, other than on Eurozone matters, the several instances of variable integration that now exist fall short of creating a two-tier EU. There is as yet no institutional separation and one does not observe an 'avant garde' group but rather several different 'arrières gardes', always consisting of a small number of states lagging behind, often just one or two but in different configurations (even if some countries appear frequently) and often seen as an anomaly, exception or temporary situation. ${ }^{75}$ While such views may be considered a rather rosy outlook on matters as bleak as those surrounding 'Grexit', let alone 'Brexit', 76 it remains a fact that the outside world still sees the EU as a single entity, albeit it one with some complications.

In foro externo, there exist various kinds of differentiation, both of a structural and of an ad hoc nature, some of them the expression of the external dimension of internal differentiation, others of an external character per se. On the structural side, examples include: the separation of the Common Foreign and Security Policy (CFSP) - the previously called 'second pillar' - from all the other common policies of the EU in terms of legal geography (the former relegated to the TEU, whereas all the rest have

Portugal, Spain, 17 September 2012, available at http://www.auswaertiges-amt.de/cae/servlet/ contentblob/626338/publicationFile/171844/120918-Abschlussbericht-Zukunftsgruppe.pdf.

72 Denmark, which also has an opt-out in this respect, did not reverse its own position on AFSJ after a negative referendum in 2015 to decide on a more flexible opt-in arrangement.

73 Hedging non-Eurozone members against the fall-out from Eurozone decisions is one of the four key EU reform demands Prime Minister Cameron has put on the table of the European Council ahead of the 'Brexit' referendum.

74 See section 4.2 below.

75 See R. Corbett, 'Two-tier Europe. Really?', in S. Blockmans (ed), loc. cit. n. 59, at pp. 8-11.

76 See the contributions to and especially the concluding chapter of M. Emerson (ed), Britain's Future in Europe: Reform, Renegotiation, Repatriation, or Secession?, 2nd edn, CEPS 2016. 
been included in the TFEU); opt-outs of the Common Security and Defence Policy (CSDP); the external dimension of AFSJ (e.g. readmission and visa facilitation agreements); and the external representation of the EU (and the Eurozone) in international financial institutions. On the ad hoc side, one can point to the notion of 'interested Member States' in external migration policy and the possibility for Member States to constructively abstain from CFSP and CSDP decision-making. As a consequence of the specificity of EU external action, this area is often approached from the perspective of 'coherence': the duty to join up different strands of external policies and deliver a single message, in spite of the underlying diversity of opinions and interests. ${ }^{77}$ Similarly, there is a perceived need to preserve 'legal homogeneity' in a wider European legal sphere covering EFTA states, enlargement and ENP countries. ${ }^{78}$

Given the high sensitivity of foreign policy matters in the context of national sovereignty, it can be argued that the whole process of developing a CFSP has, from the start, entailed differentiation-oriented deepening reforms. In that regard, innovations in the Treaties following Maastricht (Amsterdam, Nice and Lisbon) have demonstrated awareness of the need to answer the calls for 'more EU' without trying to constrain the Member States in a one-size-fits-all policy straightjacket. In order to overcome the traditional lowest-common-denominator outcomes of intergovernmental foreign-policymaking, EU reforms have therefore sought to gradually develop 'differentiating' tools like constructive abstention and qualified majority voting (Article 31(1-2) TEU), designed to streamline and bolster decision-making while still offering sovereigntyfriendly 'emergency brakes'. Whereas practice with these procedural exceptions has not expanded beyond the track record established prior to the entry into force of the Lisbon Treaty, voices are growing increasingly louder for the EU to employ them. ${ }^{79}$

In sum, differentiated integration, both in foro interno and in foro externo, is likely to gain in relevance and whip up new constitutional and institutional questions. One of the main concerns is that proliferation of different regimes applicable only to groups of Member States may undermine the effectiveness of the European Union and create a regime that would be difficult to navigate. At the same time, however, recourse to flexible integration turns out to be an important tool to push the EU agenda forward. One should not forget that countries initially opting out of certain measures are always welcome to opt in at a later stage. To put it differently, various examples of flexibility may not necessarily lead to disintegration but, on the contrary, to further, yet gradual integration.

77 See, e.g., C. Hillion, 'Tous pour un, un pour tous! Coherence in the External Relations of the European Union', in M. Cremona (ed), Developments in EU External Relations Law, Oxford University Press 2008, p. 10.

78 See A. Łazowski, 'Flexibility and Homogeneity: Two Uneasy Bedfellows', in Blockmans (ed), loc. cit., n. 59, p. 37.

79 See S. Blockmans, 'Differentiation in CFSP', LXVI-3 Studia Diplomatica (2013) p. 53; and P. Vimont, The Path to an Upgraded EU Foreign Policy, Carnegie Europe Policy Outlook, June 2015, at 6: 'Formalize the use of ad hoc groupings of member states on specific issues.' 


\section{INSTITUTIONAL INNOVATIONS 80}

\subsection{Introduction}

The Lisbon Treaty is generally remembered for having spurred more institutional than policy changes. ${ }^{81}$ This is hardly surprising bearing in mind the broad objectives behind resuscitation of parts of the Constitution after a period of reflection that followed the two referenda in France and the Netherlands. One of the main objectives was streamlining of the EU decision-making process and enhancing the efficiency of the EU institutions following the big bang enlargement in 2004. The main changes introduced by the Treaty of Lisbon affected four main institutions, that is, the European Council, the Council, the European Commission and the European Parliament. ${ }^{82}$

To analyse all reforms provided for by the Treaty of Lisbon would exceed the limits of this chapter therefore the centre of gravity in the sections that follow is on selected changes of the highest importance. ${ }^{83}$ The starting point is the institutionalisation of the European Council and its President as well as the amendment of the Council voting rules (section 4.2). This is followed by an analysis of selected reforms of the European Commission, in particular the expansion of its right of initiative (section 4.3). As with the previous revisions of the Founding Treaties, the biggest gains in power have been obtained by the European Parliament. Two areas stand out, that is, the enhanced role of the European Parliament as a co-legislator, and its grip on the nomination procedure of the Commission President. These issues are analysed in section 4.4. Finally, one of the most comprehensive reforms introduced by the Treaty of Lisbon is in the realm of EU external action. To begin with, a hybrid position of the High Representative/VicePresident was created. Furthermore, to support its activities, an equally hybrid new European External Action Service was created (section 5). Whereas these and other institutional changes have not gone as far as those laid down in the Constitutional Treaty of late, ${ }^{84}$ the EU has nevertheless been criticised for wasting too much time rearranging its deck chairs while it, like a Titanic hit by the iceberg of the 2008 global

80 This section draws in part on S. Piedrafita and S. Blockmans, 'Shifting EU Institutional Reform into High Gear', Report of the High-level Group Chaired by Danuta Hübner, CEPS, March 2014.

81 See further, inter alia, L. Pech, 'The Institutional Development of the EU Post-Lisbon: A Case of Plus ça Change?', in D. Ashiagbor, N. Countouris and I. Lianos (eds), The European Union After the Treaty of Lisbon, Cambridge University Press 2012, p. 7.

82 The Court Justice of the European Union underwent considerably modest reform, though it has been affected by the Treaty of Lisbon mainly in a ricochet of the abolition of the three pillar structure of the Union. See further Chapters 9-12 in this volume.

83 For a more general analysis see, inter alia, J-C. Piris, The Lisbon Treaty: A Legal and Political Analysis, Cambridge University Press 2010; P. Craig, The Lisbon Treaty: Law, Politics, and Treaty Reform, Oxford University Press 2010; A. Biondi, P. Eeckhout and S. Ripley (eds), EU Law after Lisbon, Oxford University Press 2012; M. Trybus and L. Rubini (eds), The Treaty of Lisbon and the Future of European Law and Policy, Edward Elgar Publishing 2012.

84 See D. Curtin, A.E. Kellermann and S. Blockmans (eds), The EU Constitution: The Best Way Forward?, T.M.C. Asser Press 2005; J-C. Piris, The Constitution for Europe: A Legal Analysis, Cambridge University Press 2006. 
financial and economic crisis, was sinking. ${ }^{85}$ The post-Lisbon evidence presented in the paragraphs that follow suggests that, whereas some damage to the cohesion of the EU's structures has indeed been incurred, the new institutional arrangements have so far been able to withstand the shock and even push integration forward.

\subsection{The European Council and the Council}

The Treaty of Lisbon has introduced numerous changes to the European Council and the Council. Not only did it clarify the competences of both institutions, it also changed the presidency rules as well as the composition of the Council meetings and reformed the voting rules. The most significant change, however, has been made in respect of the status of the European Council and the modi operandi for its functioning.

The origins of the European Council go back to the 1970s when the then EC decision-making process stalled due to political differences between the Member States, on the one hand, and rigid rules governing the functioning and voting in what was then the Council of Ministers, on the other hand. The fact that the General Affairs Council was traditionally composed of the ministers of foreign affairs, thus not exactly the apex of domestic institutions, exacerbated problems encountered in the everyday functioning of the most important EC decision-making body. As is well known, the informal gathering of heads of states and governments, which developed into the European Council, was tailored to remedy the decision-making impasse. The role of the European Council has grown with the passage of time and it has received a formal recognition in the Founding Treaties qua the Single European Act. Until the entry into force of the Treaty of Lisbon its powers were vaguely regulated in the Treaty on European Union while its proceedings were largely based on customs, not rigid procedural rules. Irrespective of this, or perhaps thanks to it, over the past two decades, the European Council has had a central role in leading and coordinating certain policies - usually partly or fully outside the 'Community method' - such as the economic governance of the Economic and Monetary Union, the Common Foreign and Security Policy and Common Security and Defence Policy, the Area of Freedom, Security and Justice, employment and social policy. 86 Occasionally, the debates have also revolved around other EU policies such as environment and energy.

The number and scope of the meetings of the European Council have increased over the years. In the past there were around three summits per year which focused on major issues in EU integration. The Lisbon Treaty confirms that the European Council shall normally meet twice every six months, but that it may meet, as per Article 15(3) TEU, in a special meeting when the situation so requires. In the face of the deepest economic and financial crises since the start of the European integration process, and confronted with increasing turbulence in its neighbourhood (the 2011 Arab uprisings and the 2014/15 crisis in Ukraine), the European Council has met seven times or more per year and increasingly decides on specific issues and day-to-day business in core policy

\footnotetext{
85 See K. Mahbubani, 'Europe's Errors', Time, 8 March 2010.

86 See J. Werts, The European Council, John Harper Publishing 2008.
} 
areas. ${ }^{87}$ No doubt the Lisbon Treaty contributed to this trend by giving the European Council the status of an EU institution (Article 13(1) TEU) as well as reinforcing its role in establishing the general political direction and priorities of the EU (Article 15(1) TEU). Not surprisingly, as a matter of principle, the European Council aspires to reach consensus. Formally, however, it can take decisions unanimously. In certain instances, qualified majority voting is required. In such cases the voting rules applicable to the Council of the European Union apply accordingly also to the European Council.

The Treaty of Lisbon also provides for the separation of the presidency in the European Council and the Council of the European Union. While the latter still remains subject to a rotation system between the Member States, the former has a full-time President. Such a move was dictated by the prerequisite of assuring continuity in the work of the European Council and the need for strong, yet co-operative leadership. The President is appointed for 2.5-year terms by the European Council itself. Interestingly enough, only a qualified majority is required in this respect. The term is renewable once so in total a person may hold the position of the President of European Council for a maximum of five years. The powers of the President are generally defined in Article 15(6) TEU. First and foremost, the President of the European Council chairs its meetings and provides impetus for future actions. Furthermore, he/she is tasked with facilitation of cohesion and consensus within the European Council. Together with the President of the European Commission, he/she also prepares and ensures the continuity of work of the European Council.

In domains such as EU economic governance, some consider that the European Council interpreted its functions too extensively, whereas others believe it was the only way to overcome the constraints that were undermining the management of the euro crisis at national level. ${ }^{88}$ Despite the fact that Article 15(1) TEU states that the European Council shall not exercise legislative functions, the European Parliament's negotiating teams have at times been confronted with statements from the Presidency, negotiating on behalf of the Council, that a particular issue has already been decided by the European Council. The Presidency is left without a margin of manoeuvre, which obstructs the purpose of the negotiations to deliver a common understanding between the European Parliament and the Council and contributes to overshadowing the rotating Presidency of the Council. Moreover, the meetings of the President's Cabinet with the 'sherpas' - representatives of the heads of government - have become a crucial forum in EU decision-making, which does not contribute to the transparency of the process and undermines the role of the General Affairs Council.

Despite the growing prominence of the European Council in EU decision-making, the mechanisms to hold it democratically accountable have not been upgraded accordingly. The President of the European Council only reports to the European Parliament after the summits, ${ }^{89}$ and often to the Enlarged Conference of Presidents instead of the Floor. Information received about the Eurozone summits is quite limited

87 See U. Puetter, The European Council and the Council: New Intergovernmentalism and Institutional Change, Oxford University Press 2014.

88 For an authoritative reflection on the debate, see W. Wessels, The European Council, Palgrave 2015.

89 This is explicitly required by Article 15(6)(d) TEU. 


\section{4}

and mainly confined to the report sent by the President of the European Council after the meetings. The President of the Eurogroup is not accountable to the European Parliament at all. Parliamentary scrutiny of European Council meetings in many Member States is also very weak. ${ }^{90}$ The deep and ongoing crisis about the position of Greece in the Eurozone has led to calls for the possibility of inviting both Presidents to report and explain the decisions on reinforced budgetary surveillance, the coordination of economic policies, the excessive deficit procedures and macroeconomic imbalances. As Member States are locked in recriminations over their handling of the 'Grexit' crisis, voices are growing louder that Eurozone governance be strengthened, complete with 'strong and innovative democratic control mechanisms within the existing Treaty structure, making sure that the all-important decisions at the European level in a context of increased sovereignty-sharing and risk-sharing find direct legitimation by the European parliament and national parliaments'.${ }^{91}$

The Council of the European Union has also undergone considerable changes as a result of the Treaty of Lisbon. Its powers have been clarified in Article 16 TEU. Furthermore, the presidency system as well as the composition of its meetings has been reformed. As already noted, the role of the presidency has been further reduced by practice based on the system designed by the Treaty of Lisbon. Most importantly, however, the ever contentious voting rules have been considerably revised. To begin with, qualified majority voting is now the general rule, while unanimity is an exception. The double majority system established by the Lisbon Treaty for qualified majority voting in the Council entered into force on 1 November 2014. The shift in the balance of power, however, will not be fully effective before April 2017, given the possibility for Member States to invoke the rules established by the Treaty of Nice up to that date. ${ }^{92}$ While the new voting system in the Council promises to do away with the difficult negotiations of the past among Member States to reallocate voting weights, it is questionable whether it will achieve its ultimate aim to substantially improve democratic legitimacy and efficiency. ${ }^{93}$

90 C. Hefftler, V. Kreilinger, O. Rozenberg and W. Wessels, 'National Parliaments: Their Emerging Control over the European Council', Notre Europe Policy Paper 89, Notre Europe, Paris, 29 March 2013.

91 See J. Delors et al., 'After the Greek Deal: Three Dangers and Three Opportunities Why it is Urgent to Complete EMU', Notre Europe Tribune, 22 July 2015, at 3, with reference to the Five Presidents' Report 'Completing Europe's Economic and Monetary Union', 22 June 2015, available at http://ec.europa.eu/priorities/economic-monetary-union/docs/5-presidentsreport_en.pdf. See also President Hollande's suggestions in this respect, at http://www.lejdd.fr/ Politique/Francois-Hollande-Ce-qui-nous-menace-ce-n-est-pas-l-exces-d-Europe-mais-soninsuffisance-742998.

92 See Article 3 of Protocol No 36 on transitional provisions annexed to the Founding Treaties.

93 See S. Piedrafita, 'A New Balance of Power in the Council? Yes, But Not Yet ...', CEPS Commentary, 19 December 2014. 


\subsection{The European Commission}

The third crucial EU institution involved in the daily functioning of the European Union is the European Commission. Its considerable powers are now defined in Article 17 TEU and include acting in the interest of the European Union and proposing legislation as well as scrutiny of compliance by the Member States.

Notwithstanding the growing agenda-setting powers of the European Council, the European Commission remains a key player in the initiation and implementation phases of the decision-making process. This has been strengthened by the abolition of the third pillar of the European Union and the consequential, though gradual, increase in the powers of the European Commission. To begin with, the European Commission has the right to propose legislation for police and judicial co-operation in criminal matters. However, it currently shares this right with a quarter of the Member States. ${ }^{94}$ Following the end of the transitional period laid down in Protocol No 36 to the Founding Treaties, the European Commission - together with the Court of Justice - currently scrutinises the compliance of the Member States with EU legislation in criminal matters (whether pre- or post-Lisbon). This, no doubt, is an important step forward, which hopefully will contribute to the effectiveness of EU law in this area. It should be noted that pre-Lisbon evidence demonstrates notorious non-compliance by the Member States.

The efficient and legitimate exercise of the Commission's right of initiative is closely linked to the organisation of the college of Commissioners. The principle of collegiality, which should govern decision-making in the European Commission (Article 17(6) TEU), guarantees the equal participation of all the Commissioners and the collective responsibility for the decisions taken. As a collegiate body, the Commission is held to promote the general interest of the Union and carry out its functions independently (Article 17(1) and (3) TEU). In practice, however, working methods and political inclinations have varied from one Commission to the next. During the Barroso II Commission (2009-2014), the high number of Commissioners and Directorates (33 DGs and 11 Services) made effective internal coordination more difficult and increased the tendency to negotiate dossiers between the President and the respective Commissioner(s) on a selective basis rather than through discussions within the College. Few decisions were ever put to a vote, despite the controversy generated by some of them. A good example was the proposal for a Directive on Tobacco Products, ${ }^{95}$ which led to the adoption of contentious European Parliament and Council Directive 2014/40/EU. ${ }^{96}$

94 It should be noted that no such threshold was provided in the previously applicable rules, under which a single Member State had the right to propose legislation in this area.

95 Proposal for a Directive of the European Parliament and of the Council on the approximation of the laws, regulations and administrative provisions of the Member States concerning the manufacture, presentation and sale of tobacco and related products, COM (2012) 788 final.

96 Directive 2014/40/EU of the European Parliament and of the Council of 3 April 2014 on the approximation of the laws, regulations and administrative provisions of the Member States concerning the manufacture, presentation and sale of tobacco and related products and repealing Directive 2001/37/EC, OJ 2014 L 127/1. A challenge to the legality of this Directive has failed at the Court of Justice, see Case C-358/14, Republic of Poland $v$ European Parliament and Council of the European Union, ECLI:EU:C:2016:323. 
This practice has proved counterproductive in terms of collegiality and has favoured a silo approach to policy-making. In fact, this practice stood in stark contrast to the Lisbon Treaty's spirit of a more holistic approach in dealing with increasing interdependencies between policy areas. Another downside of the large size of the Barroso II Commission was that it created a bias in favour of more (critics say 'excessive') legislation. Between 2010 and 2014, the Barroso II Commission adopted 605 legislative proposals, as well as another 2074 initiatives such as communications, guidelines, reports, recommendations, Commission regulations, and Green and White Papers. ${ }^{97}$

To address these shortcomings, the current President Jean-Claude Juncker has made amends to the Commission's structure and strategic planning. Whereas a reduction in the number of Commissioners continues to be legally and politically unrealistic, clustering the Commissioners with related portfolios (energy; jobs, growth, investment and competitiveness; the digital single market; the euro; external action) was arguably the best option to enhance collegial decision-making and improve the independence, efficiency and transparency of the European Commission. Bringing together three or four portfolios, each under the leadership of a Vice-President, the clusters of Commissioners now present their common position for the College to decide. The re-organisation of the Commission's portfolios responded to the strategic plan presented by Jean-Claude Juncker, then a Commission President designate, to the European Parliament in July 2014. At the beginning of its mandate, the new Commission also developed a legislative plan for 2015, which was subject to the scrutiny of the European Parliament and the Council. Despite its shortcomings, ${ }^{98}$ the Commission's new 'Better Regulation' agenda should contribute to improving the efficiency, political accountability and transparency of the EU legislative process. The appointment of Frans Timmermans ${ }^{99}$ as First Vice-President responsible for, inter alia, better regulation underlines the importance attached to the issue by the 'political' Juncker I Commission, ${ }^{100}$ as it coincided with one of the central EU reform demands of UK Prime Minister David Cameron ahead of the 'in or out' referendum (i.e. 'cutting red tape'). In an effort to deal with the UK's other reform demands ahead of the referendum, a temporary 'Brexit' task force was created in 2015, pooling resources from across the Commission to manage files and outreach sensitive to the UK. This novel structure followed the example of the 'Support Group for Ukraine', which however also involves staff seconded from the EEAS and the Member States.

Apart from exercising its right of initiative, the European Commission has continued to play an essential role in the implementation phase of the decision-making cycle. One

97 Data collected from the EUR-LEX database and compiled in Graph 1 in S. Piedrafita and S. Blockmans, 'Shifting EU Institutional Reform into High Gear', Report of the High-level Group Chaired by Danuta Hübner, CEPS, March 2014, at p. 4.

98 See A. Renda, 'A Quick Assessment of the EC's New Better Regulation Package', CEPS Special Report, April 2015. Vice-Commissioner Timmermans seems to have interpreted 'better' as primarily meaning 'less' regulation.

99 Former Minister of Foreign Affairs of the Netherlands who oversaw a 'subsidiarity exercise' across the Dutch administration in 2013. See Dutch Ministry of Foreign Affairs, Uitkomsten subsidiariteitsexercitie, MINBUZA-2013.184321, 21 June 2013.

100 See V. Pop, 'Let's Get Political. Juncker-Style', Wall Street Journal, Real Time Brussels blog, 7 May 2015. 
aspect of that role is to oversee the application of EU law. Despite the Commission's efforts to improve the situation, Member States still often fail to fully comply with their responsibilities to transpose, apply and enforce EU legislation. In the post-Lisbon setting, infractions remain high on average. In 2012, for instance, following an initial assessment of more than 2800 complaints, the Commission opened bilateral discussions with the Member State concerned in relation to 621 complaints. ${ }^{101}$ That year, the Commission also initiated the first bilateral discussions with Member States from 791 investigations launched on its own initiative. While the Commission had launched new initiatives such as the EU pilot to improve the application of EU law, the transposition of EU legislation into Member States was still deficient. Their support of SOLVIT tools, which provide citizens and business with a fast track to find pragmatic solutions to problems caused by a breach of EU law by a public authority, was also weak. The Commission itself had also improved the handling and reduced the time of the infringement procedures, but this was still long. At the end of 2012, 1343 infringement cases remained open (compared to 1775 in 2011 and 2092 in 2010). ${ }^{102}$ During that year, the Court delivered 46 judgments under Article 258 TFEU, 42 of which favoured the Commission's position. This situation has not vastly improved in subsequent years. ${ }^{103}$

\subsection{The European Parliament}

Going by successive Eurobarometer polls conducted over the past five years, the financial and economic crisis has increased the perception of the EU's democratic deficit. Democratic legitimacy is assessed in terms of 'participation', 'political accountability' and 'institutional balance'. The question which we ask ourselves is whether the institutional changes introduced in the Lisbon Treaty have helped to reverse the downward trend of the past years. The evidence collected presents a mixed bag. On the one hand the Treaty of Lisbon, similarly to the previous revisions of the Founding Treaties, has extended the powers of the European Parliament. On the other hand, the practice that has followed the most recent changes triggers numerous questions about the participation of EU citizens in the process and the European Parliament itself in daily functioning of the European Union. At the same time the past few years have invigorated the debate about the democratic legitimacy of the Union and the contribution of the European Parliament in this respect. These issues are addressed in turn.

In terms of 'participation', the above-mentioned trend is certainly reflected in voter turnout in the elections to the European Parliament, which hit an historic low of 42.61 per cent in 2014. This was not an ad hoc situation, but a proof of ever-consistent trend. Since the first general elections to the European Parliament in 1979, the voters have

101 The figures in this paragraph are drawn from the General Secretariat's 30th Annual Report on monitoring the application of EU law (2012), COM (2013) 726 final.

102 In 128 procedures, the Commission could not yet confirm whether the Member States concerned had complied with the Court judgments.

103 More recent annual reports from the Commission's monitoring of the application of EU law are available at http://ec.europa.eu/atwork/applying-eu-law/infringements-proceedings/ annual-reports/index_en.htm. 
been constantly losing interest and faith in the European Parliament. It is notable that nationalist, Eurosceptic and even anti-EU forces of different political shades and at both ends of the spectrum were among the major winners of the 2014 European Parliament elections. Their rise, also at national level, is characteristic of voters' dissatisfaction with mainstream parties' financial and economic policies, areas which increasingly fall under EU scrutiny. Ironically, the anti-EU mood has therefore turned the European Parliament political spectrum towards a more accurate reflection of citizens' preferences and dismay. At the same time, general elections at national level are gradually being 'Europeanised', albeit due to negative perceptions of the EU (cf. Syriza in Greece, the Front National in France, Podemos in Spain).

'Participation' in the institutional sense holds some examples geared towards strengthening the EU integration project, but arguably they are too small to make a difference in overall political terms. One example relates to the right of the European Parliament to ask the Commission to propose legislation (Article 225 TFEU). This potentially powerful tool is hardly used by the European Parliament. In fact, in the last legislature fewer than 20 own-initiative legislative reports were adopted. Another potentially more promising example relates to the citizens' initiative (Article 11(4) TEU), which enables one million EU citizens, who are nationals of at least one quarter of the Member States, to call directly on the European Commission to propose a legal act in an area where the Member States have conferred powers to the EU level. ${ }^{104}$ The Commission, however, is not obliged to act. In the first three years of operation, ${ }^{105}$ the introduction of this instrument of direct democracy has not turned out to be the success that many civil society organisations hoped it would be. So far, only three initiatives (on EU exchange programmes, the right to drinking water and stopping vivisection) have been actively entertained by the European Commission. All other submissions have been discarded for a host of reasons. ${ }^{106} \mathrm{~A}$ third example relates to the involvement of national parliaments in the work of the European Parliament. ${ }^{107}$ Inter-parliamentary committee meetings are organised by a committee of the EP to discuss specific legislative proposals with the members of the respective standing committees at national level. However, such co-operation is, by and large, still a subdued affair and could be upgraded in terms of visibility and influence. ${ }^{108}$ Proposals from national

104 Detailed rules are provided in Regulation (EU) No 211/2011 of the European Parliament and of the Council of 16 February 2011 on the citizens' initiative, OJ 2011 L 65/1. See further, inter alia, M. Dougan, 'What Are We to Make of the Citizens' Initiative?', 48 CMLRev (2011) p. 1807; J. Organ, 'Decommissioning Direct Democracy? A Critical Analysis of Commission Decision-making on the Legal Admissibility of European Citizens' Initiative Proposals', 10 EUConst (2014) p. 422.

105 The ECI was launched on 9 May 2012 with the registration of 'Fraternité 2020', an initiative to enhance EU exchange programmes such as Erasmus to contribute to a united Europe based on solidarity among citizens.

106 For more information see http://ec.europa.eu/citizens-initiative/public/welcome?lg=en.

107 For a more general appraisal of the role of national parliaments in the EU system see Chapter 4 in this volume.

108 In particular, the Commission and the Presidency should participate at the highest level possible in the recently created Inter-Parliamentary Conference on Economic and Financial Governance of the EU (cf. Article 13 TSCG). 
parliaments for new EU legislation have not exactly been forthcoming either: the first such 'green card' was only presented in July 2015, when 16 Chairpersons of committees of national parliaments called on the European Commission to take action to combat food waste. ${ }^{109}$

In terms of 'political accountability', the democratic legitimacy of the EU has slightly improved, due to, on the one hand, the increased political power of the European Parliament in the appointment procedure of the Commission President (cf. Spitzenkandidaten), and the involvement of national parliaments in subsidiarity control (Article 5 TEU and Protocol 2), on the other. Whereas the latter is essential to pre-empt unnecessary legislation and ensure that decisions are taken as closely as possible to the citizens, seven years of practice with the early warning mechanism established by the Lisbon Treaty reveals a number of shortcomings, ranging from a low and uneven participation across national parliaments ${ }^{110}$ and the lack of a common approach to the subsidiarity principle across national parliaments, to their complaints that the reply letters from the Commission are sometimes too general and do not properly address the specific objections raised. ${ }^{111}$ With regard to the former, pursuant to the procedure provided for the first time by the Lisbon Treaty in Article 17(7) TEU, the main European political families campaigned for the 2014 EP elections with a Spitzenkandidat, that is, a lead candidate whom they would name as President of the Commission in the event of success at the ballot box. ${ }^{112}$ Whereas commentators have argued that the provision which obliges the European Council to propose a candidate for Commission President by 'taking into account' the elections to the European Parliament does not mean that such a nomination should be automatic, ${ }^{113}$ practice with the experiment has shown that the transparency of the system has de facto forced the Head of State and Government to follow suit. ${ }^{114}$

This leads us to the third element in the test to gauge the level of democratic legitimacy which the Lisbon Treaty has instilled in the EU: 'institutional balance'. The Spitzenkandidaten experiment was the object of heated debate for several months prior to the 2014 elections to the European Parliament, prompting much speculation as to the changes it would bring to the balance of power between the EU institutions. While it is obvious that the procedure has granted the new Commission President a

109 See http://www.parliament.uk/documents/lords-committees/eu-select/green-card/greencard-on-food-waste.pdf.

110 Annual Report 2012 on Subsidiarity and Proportionality, European Commission, COM (2013) 566 final, Brussels, 30 July 2013. See further, Chapter 4 in this volume.

111 See the 16th Bi-annual Report: Developments in European Union Procedures and Practices Relevant to Parliamentary Scrutiny, COSAC, October 2011; and S. Blockmans, J. Hoevenaars, A. Schout and J.M. Wiersma, 'From Subsidiarity to Better EU Governance: A Practical Reform Agenda for the EU', Clingendael/CEPS Report, March 2014.

112 The European Conservatives and Reformists (ECR) family was the only one that decided not to nominate anyone.

113 The text was left deliberately ambiguous to reach a compromise in the Convention between those who wanted to 'politicise' the election of the Commission President to strengthen the democratic legitimacy of the position and to raise citizens' awareness about the EU and the EP elections, and those who objected to such a development.

114 See further Chapter 6 in this volume. See also D. Dinan, 'Governance and Institutions: The Year of the Spitzenkandidaten', 53 JCMS (2015) p. 93. 
greater democratic mandate than any of his predecessors enjoyed, it is hard to argue that the procedure has substantially changed the institutional balance in favour of the Commission. With regard to the Council of the European Union, the new Commission President is still not able to act without the Member States for the nomination of his fellows in the college. ${ }^{115}$ Moreover, the 'competitive cooperation' 116 between Council and Commission concerning the setting of the policy agenda will remain as before. Also, the new President continues to depend on the broad support of the European Council, and will still occasionally need an absolute majority of at least 376 votes in the European Parliament. Even if the Commission President, J-C. Juncker has emerged from the interplay between European political parties and is thus under more intense pressure to promote the kind of policies that the main political parties in the European Parliament called for during the electoral campaign, the Spitzenkandidaten system has not turned the relationship between the executive and the co-legislator into the kind of parliamentary democracy found in the Member States. The only 'coup d'état' that has matured with the Spitzenkandidaten experiment has been the one directed against the process of appointing the European Commission President in horse-trading behind closed doors in the European Council. ${ }^{117}$ This is ultimately a victory obtained by the European political parties, with the agreement of Heads of State and Government, most of whom bought into the democratically meritorious system when they voted in their capacity as de facto "grands électeurs" at their respective party congresses'.118 Although the new procedure entails 'a number of political, institutional and "thus" constitutional ambiguities', 119 it has rendered the process more transparent, if not more democratic. It will be hard for the European Council to put this genie back into the bottle. It is more likely that the Spitzenkandidaten procedure will trigger further changes, with more high-calibre politicians seeking to advance their careers in the European political party system in future European Parliament elections. ${ }^{120}$

115 As Baldoli, Gänzle and Shackleton point out, 'there is something of a paradox in having a more transparent method of election of the President going hand-in-hand with the traditional system of backroom deals and horse-trading about the names of Commissioners and their portfolios'. See R. Baldoli, S. Gänzle and M. Shackleton, 'Overthrowing Secrecy: The Spitzenkandidaten Experiment and a New Chance for a European Party System', CEPS Commentary, 4 August 2014.

116 P. Bocquillon and M. Dobbels, 'An Elephant on the 13th Floor of the Berlaymont? European Council and Commission Relations in Legislative Agenda Setting', 20 JEPP (2013) p. 1 , at p. 15 .

117 See P. De Matteis, 'EU Faces Prospect of “Coup d'État” by European Council', The Parliament Magazine, 5 June 2014.

118 See M. Incerti, 'Never mind the Spitzenkandidaten: It's all about politics', CEPS Commentary, 6 June 2014: 'The prime ministers belonging to, for example, the European Peoples' Party, in a sense ratified that interpretation of the Treaty by approving the respective Spitzenkandidat.'

119 Y. Bertoncini, 'New President, "New" Constitution?', Notre Europe Tribune, 23 July 2014.

120 See R. Baldoli, S. Gänzle and M. Shackleton, 'Overthrowing Secrecy: The Spitzenkandidaten Experiment and a New Chance for a European Party System', CEPS Commentary, 4 August 2014. 
Also in terms of 'institutional balance', the European Parliament has acquired a more central role in the legislative process. The use of the co-decision procedure has not ceased to grow over time. In fact, it became the ordinary legislative procedure (OLP) under the Lisbon Treaty, which extended its use to cover up to 83 policy areas and limited the use of special legislative procedures. Council acts that only require the consultation of the European Parliament are confined to the regulation of social security and social protection, own resources, taxation, fiscal provisions in environment and energy and a few issues within the JHA domain (such as measures concerning passports, identity cards and residence permits, family law with cross-border implications and operational police co-operation). Special procedures that require the consent of the European Parliament are used for measures to combat discrimination, the extension of citizenship-related rights, the European Public Prosecutor's Office, ${ }^{121}$ the uniform electoral procedure and the multi-annual financial framework. The Lisbon Treaty also reinforced the role of the European Parliament in the budgetary procedure, where the Council is obliged to go to conciliation with the EP if the latter does not agree to the Commission's proposal as amended by the Council in the first reading.

As a result of the European Parliament's stronger role in the legislative process, informal tripartite negotiations with the Council and the Commission have intensified and new inter- and intra-institutional challenges have emerged. ${ }^{122}$ There has in fact been a rise of agreements at first reading. ${ }^{123}$ The first reading in the European Parliament only requires a simple majority of the votes cast and the Council can approve the EP's amendments by a qualified majority. Therefore, it is clearly in the interest of the Parliament to reach early agreements. Amendments to the Council's Common Position in the second reading require the absolute majority of the component members of the EP and the subsequent endorsement of the Council - by qualified majority if they have the Commission's positive opinion or unanimity otherwise. While many Presidencies actively encourage first-reading agreements, it is clear that the Council has more control over the outcome by taking the procedure to a second reading. After all, the Common Position will then become the proposal to be negotiated, and its approval without amendments only requires a simple majority in the EP. The use of Conciliation (third reading) in the event of a stalemate at second reading has become almost obsolete (except for the special budget procedures). ${ }^{124}$ Despite the fact that trialogue negotiations facilitate early agreements and make the process more

121 See L. Erkelens, A.H. Meij and M. Pawlik (eds), The European Public Prosecutor's Office: An Extended Arm or a Two-Headed Dragon?, T.M.C. Asser Press 2014.

122 Trialogue meetings may vary from very technical discussions (involving staff of the three main administrations) to very political discussions (involving Ministers and Commissioners). As a general rule, they involve the chair of the relevant EP Committee - who usually also chairs the negotiations - and the rapporteur from the EP (often accompanied by shadow rapporteurs from other political groups), the chair of COREPER (or the relevant Council working party assisted by the General Secretariat of the Council), and representatives of the Commission (usually the expert in charge of the dossier and his/her direct superior assisted by the Secretariat-General and Legal Service).

123 See B. Fox, 'Secret EU Lawmaking: The Triumph of the Trialogue', EUObserver, 4 April 2014.

124 Ibid. 


\section{2}

efficient overall, a number of shortcomings have nevertheless been identified: the legal services of the three institutions sometimes fail to provide consistent legal opinions, which complicates and might even stall the negotiations; in the EP, delays in the first reading are usually caused by difficulties to identify the lead committee, a trend that has grown as a result of the increasingly holistic nature of policy proposals; ${ }^{125}$ parliamentary expertise on highly complex issues is not plentiful and is allocated asymmetrically across members and committees, which might also undermine the EP's negotiating position; ${ }^{126}$ and the Council often takes a long time to agree on a common approach, while representatives of the Member States are sometimes adamant about securing exceptions, at the expense of the clarity and the quality of the piece of legislation under discussion.

\section{INSTITUTIONAL INNOVATIONS IN THE REALM OF EU EXTERNAL ACTION}

In foro externo, the European Council has been tasked with the identification of the strategic interests and objectives of the Union (Article 22(1) TEU), as well as the external representation of the Union at Presidential level in the area of the CFSP (Article 15(6) TEU). Since the entry into force of the Lisbon Treaty, the onus has been on the European Council to identify the strategic interests and objectives of the Union that relate to the external action of the Union and to take decisions which 'may concern the relations with a specific country or region or may be thematic in approach'. Whereas the first President, Herman van Rompuy, started off a long-overdue and necessary debate on the EU's strategic priorities, the first European Council Summit to that effect was not a great success as it amounted to not much more than a general brainstorming exercise in which not even the term 'strategic partner' was defined. ${ }^{127}$ It was only when the European External Action Service became fully operational and when Russia revealed itself to be more of a strategic 'competitor' than a 'partner' of the EU with regard to relations with Ukraine, that the European Council engaged in a more thorough process to review the 2003 European Security Strategy. ${ }^{128}$

During his first three days in office, European Council President Donald Tusk reached out by telephone to both Presidents Barrack Obama and Xi Jinping. In his talk with Obama, Tusk stressed the strategic importance of the Transatlantic Trade and Investment Partnership, as well as their common stance vis-à-vis the war in Ukraine. The telephone conversation with Xi Jinping was a first opportunity to emphasise the

125 Rule 188, Rules of Procedure, 7th edition, European Parliament, July 2013.

126 MEPs need experts' inputs to build up their positions and draft the amendments. They have regular contacts with interest groups. Given the enhanced role of the EP in the legislative process, large firms have increased the resources they devote to lobbying MEPs. A growing presence of lobbyists in the EP's activities adds up to the strong influence that some interest groups already exert in the capitals. See S. Hix and B. Høyland, The Political System of the European Union, Palgrave 2011, at pp. 159-185.

127 European Council Conclusions of 16 September 2010, Press Release EUCO 21/10, CO EUR 16, CONCL 3.

128 A new European Global Strategy is expected to be endorsed in 2016. 
importance Tusk attaches to developing a strong strategic relationship with China to the benefit of the European Union, China and the world. The two leaders also discussed the importance of territorial integrity, again in the context of Ukraine. What these two examples show is, firstly, that while developing strong partnerships with the G2, and personal relationships with their leaders, is of strategic importance to the EU, what happens in its immediate neighbourhood exercises it even more. In a world that has become flatter due to globalisation, geography still matters. Secondly, Tusk's actions provided continuity with his predecessor's role in EU external action. While the tone and emphasis in their approach may differ slightly, the EU's strategic interests remain the same. As 'coordinator-in-chief', President Tusk can only go as far as the leaders of the EU Member States will allow him to. What the crisis over Ukraine has made clear is that CFSP matters are increasingly Chefsache. The adoption of sanctions against Russia is not something which, at first, would be left to the Foreign Affairs Council to decide.

While primary authority for policy choices in CFSP and CSDP continues to rest with the European Council and the Council, ${ }^{129}$ it is the High Representative of the Union for Foreign Affairs and Security Policy (HR $)^{130}$ who 'conducts' the Union's foreign, security and defence policies (Article 18(2) TEU), contributes proposals to the development of those policies, and - together with the Council - ensures compliance by the Member States with their CFSP obligations (Article 24(3) TEU). The Commission remains responsible for policy initiation, implementation and external representation in the other domains of EU external action. To enhance coordination in the overcrowded realm of EU external action, the HR has been tasked to take part in the work of the European Council (Article 15(2) TEU), preside over the Foreign Affairs Council (Article 18(2) TEU), and hold the post of Vice-President of the European Commission (VP; Article 17(4) TEU). This 'triple-hatted' person is in practice the big coordinator of EU foreign affairs: the HR/VP is held to assist the Council and the Commission in ensuring coherence between the different areas of the Union's external action and between these and the EU's other policies. ${ }^{131}$ When properly carried out, the upgraded position of HR/VP thus allows for a more joined up, more visible and more effective EU on the international scene. However, with the incumbent being subject to conflicting loyalties, the HR/VP could also suffer from institutional schizophrenia. ${ }^{132}$ To assist the HR/VP in what might indeed seem like a mission impossible, the Lisbon Treaty foresaw the creation of a new diplomatic service of the EU, the idea for which originated during the European Convention in the Working Group on External

\footnotetext{
129 Articles 22-26 TEU, respectively Articles 26(2) and 28 TEU.

130 The name change (compare the title of the pre-Lisbon position) reflects the fact that it has become clear that the HR indeed represents the Union and not the (collective) Member States. Even the President of the European Council exercises his position's external competences 'without prejudice to the powers of the High Representative of the Union for Foreign Affairs and Security Policy' (Article 15(6)d TEU).

131 See Articles 18(4), 21(3) and 26(2) TEU.

132 See Y. Devuyst, 'The European Union's Institutional Balance after the Treaty of Lisbon: "Community Method" and "Democratic Deficit" Reassessed', 39 GJIL (2008) p. 247, at pp. 294-295.
} 
Action. ${ }^{133}$ On the basis of a single procedural rule provided in Article 27(3) TEU, the European External Action Service (EEAS) was created by way of a Council Decision. ${ }^{134}$ This was followed by the adoption of three parallel legislative acts, which changed the EU's financial and staff regulations and established a start-up budget for the EEAS. ${ }^{135}$ The completion of this complex process in barely six months triggered one insider to call it a 'Guinness record for speed'. ${ }^{136}$ The EEAS was launched on 1 December 2010 and became operational a month later, on 1 January 2011. Having found their space in an overcrowded theatre, the HR/VP and the EEAS seem increasingly able to provide the kind of assistance to the European Council, Council and Commission that is needed to attain a higher level of coherence in EU external action. The facilitated dialogue between Kosovo and Serbia, the maintenance of the EU sanctions regime against Russia, and the adoption of measures to deal with the migration crisis in the South are cases in point. The philosophy embedded within the 2013 Joint Communication on the EU's comprehensive approach to external conflict and crises is gradually expanding beyond the classic security-development nexus, into other areas like migration, climate change and energy. ${ }^{137}$

In order to develop a more coherent, effective and visible EU foreign policy, the Lisbon Treaty not only foresaw the institutional innovations described above, it also introduced a fundamental change at another level: it merged the objectives of the Union's external policies, from security over development to trade and environment in Article 21 TEU. While this merger could, in theory, lead to more policy coherence, practice has shown that the provision cannot paper over the cracks which remain between the CFSP - which, as noted above, remains located in the TEU due to its 'specificity' - and all other EU policy areas laid down in the TFEU. Thus far, the Court has in its post-Lisbon case law not clarified how to determine which legal regime should take legal precedence when joining up the different strands of EU foreign policy. Yet, it has been given a new opportunity by the European Parliament in a 'cross-pillar' dispute with the Council about the proper legal basis for an international agreement with Tanzania on the transfer for trial of pirates apprehended through the

133 CONV 459/02, Final Report of Working Group VII on External Action, Brussels, 16 December 2002, at 6-7.

134 Council Decision 2010/427/EU of 26 July 2010 establishing the organisation and functioning of the European External Action Service, OJ 2010 L 201/30. See S. Blockmans and C. Hillion (eds), EEAS 2.0: A Legal Commentary on Council Decision 2010/427/EU Establishing the Organisation and Functioning of the European External Action Service, CEPS 2013.

135 Regulation No 1081/2010 on the Financial Regulation applicable to the general budget of the European Communities, as regards the European External Action Service, OJ 2010 L 311/9; Regulation No 1080/2010 amending the Staff Regulations of Officials of the European Communities and the Conditions of Employment of Other Servants of those Communities, OJ 2010 L 311/1; and European Parliament resolution of 20 October 2010 on Council's position on Draft amending budget No 6/2010 of the European Union for the financial year 2010 (13475/2010).

136 See P. Skytte Christoffersen, 'A Guinness Record for Speed', in E. Drieskens and L. Van Schaik (eds), The European External Action Service: Preparing for Success, Clingendael Paper No. 1 (2010).

137 JOIN (2013) 30 final, Brussels, 11 December 2013. 
CSDP's Operation Atalanta. ${ }^{138}$ The Court has arguably shed light on the criteria applicable to the competence delimitation between the CFSP and TFEU-based policies of the Union. There is no doubt that such interventions are badly needed. A cliché it may be, but as long as EU institutions cannot sort out their internal differences, this is detrimental to the attainment of the Union's external action objectives and erodes the EU's global credibility.

\section{CONCLUSIONS}

This chapter has provided readers with an analysis of the main reforms introduced by the Treaty of Lisbon in respect of the constitutional foundations of the European Union as well as its institutional structure. It is rather clear that the record is mixed. In some respects the most recent treaty revision has introduced some streamlining into the existing system, yet, in many others, it has failed to meet the general objectives laid down in the Laeken Declaration of the European Council.

Barely seven years after the entry into force of the Lisbon Treaty, there are growing concerns about the unity, efficiency and democratic legitimacy of the EU political system. The implementation of the treaty provisions reforming the institutions and the decision-making procedures and, especially, the management of the euro crisis have raised new challenges and re-opened questions that the Lisbon Treaty was supposed to have answered. Differentiated integration through either enhanced co-operation or international agreements outside the EU legal framework, the salient role of the European Council in the EU decision-making process and the shift of implementing and supervisory powers from the national to the EU level in the fiscal and financial domains, have all affected the very fundamentals of the EU, its institutional balance and democratic legitimacy.

In the future, a revision of the treaties to address some of these concerns might be inescapable, but today's political climate is not favourable. Until treaty revision happens, we are likely to witness a number of institutional changes undertaken within the confines of the current treaties to improve the efficiency and democratic legitimacy of the institutions and protect the EU's integrity.

138 See, e.g., Case C-658/11, European Parliament $v$ Council (Mauritius Agreement), ECLI:EU:C:2014:2025; Case C-263/14, European Parliament v Council, ECLI:EU:C:2016:435). See, generally, P. Koutrakos, EU International Relations Law, 2nd edn, Hart Publishing 2015, at pp. 149-150. 